\title{
PENGARUH PEMBERIAN BEBERAPA JENIS ZPT ALAMI DAN PERBEDAAN UKURAN DIAMETER BATANG TERHADAP PERTUMBUHAN SETEK JAMBU BIJI (Psidium guajava L.)
}

\author{
Anggia Febriani $^{\left.1^{*}\right)}$ dan Rasdanelwati ${ }^{1)}$ \\ ${ }^{1)}$ Mahasiswa Prodi Jurusan Budidaya Tanaman Hortikultura, Jurusan Budidaya Tanaman Pangan, \\ Politeknik Pertanian Negeri Payakumbuh \\ ${ }^{2}$ Dosen Program Studi Budi Daya Tanaman Hortikultura, Politeknik Pertanian Negeri Payakumbuh \\ ${ }^{*}$ Email : anggiafebriani3@gmail.com.
}

\begin{abstract}
ABSTRAK
Tanaman jambu biji (Psidium guajava L.) ditanam hampir diseluruh wilayah nusantara dan termasuk buah komersial karena sangat dikenal oleh masyarakat. Salah satu upaya untuk meningkatkan produksi jambu biji adalah melalui perbanyakan vegetatif setek. bahan setek memiliki keterkaitan dengan tersedianya cadangan makanan pada masing-masing bagian bahan setek. Ukuran setek berpengaruh terhadap keberhasilan perbanyakan tanaman. keberhasilan setek jambu biji juga didukung pleh pemberian zat pengatur tumbuh (ZPT) guna mempercepat pertumbuhan setek dengan harapan agar diperoleh hasil yan cepat dan jumlah yang banyak. Tujuan dari penelitian ini adalah : 1). Mengetahui pengaruh pemberian beberapa jenis ZPT alami dan perbedaan ukuran diameter batang terhadap pertumbuhan setek jambu biji. 2). Mendapatkan ZPT alami dan ukuran diameter batang yang terbaik untuk pertumbuhan setek jambu biji. Percobaan ini dilakukan dikebun percobaan Aripan, Balai Penelitian Tanaman Buah Tropika, Solok, Sumatera Barat, dengan ketinggian tempat $435 \mathrm{~m}$ dpl. Kegiatan ini dilaksanakan selama 2 bulan yaitu mulai dari 4 Maret- 3 Mei 2021. Percobaan ini dilakukan dengan dua perlakuan ZPT alami yaitu bawang merah dan air kelapa serta ukuran diameter batang yang digunakan yaitu diameter batang kecil $(0,3-0,5 \mathrm{~cm})$ dan diameter batang besar $(0,7-1,5 \mathrm{~cm})$ yang terdiri dari perlakuan. Parameter pangamatan yaitu : persentase tumbuh $(\%)$, hari mucul tunas, jumlah tunas, panjang tunas, jumlah daun, persentase setek yang berkalus, dan persentase setek yang berakar.
\end{abstract}

Kata kunci : Jambu biji, perbanyakan vegetatif, stek, ZPT alami, diamater batang

\section{PENDAHULUAN}

Tanaman jambu biji (Psidium guajava L.) ditanam hampir diseluruh wilayah nusantara dan termasuk buah komersial karena sangat dikenal oleh masyarakat. Tanaman jambu biji berasal dari Amerika Tengah, lalu penyebaran tanaman ini meluas ke kawasan Asia Tenggara dan kewilayah Indonesia melalui Thailand. Tanaman jambu biji dapat diperbanyak dengan dua cara, yaitu secara vegetatif (okulasi, cangkok dan setek) dan generatif (biji).

Salah satu upaya untuk meningkatkan produksi jambu biji adalah melalui perbanyakan vegetatif yaitu setek. Perbanyakan tanaman dengan cara setek memiliki banyak kelebihan diantaranya memiliki sifat yang sama dengan induknya, tanaman baru umumnya cepat berbuah, tanaman yang dihasilkan memiliki keseragaman, dan merupakan salah satu cara penyediaan bibit secara cepat dalam jumlah yang banyak. Bahan yang digunakan untuk bahan setek ini yaitu batang atau cabang yang diambil dari pohon induk tanaman. Bahan setek memilki keterkaitan dengan tersedianya cadangan makanan pada masing masing bagian bahan setek yang akan menentukan potensi pertumbuhan dan perkembangan setek.

Keberhasilan setek jambu biji juga didukung oleh pemberian ZPT (Zat Pengatur Tumbuh) guna mempercepat pertumbuhan tanaman dengan harapan agar diperoleh hasil yang cepat dan jumlah yang besar. Pemberian zat pengatur tumbuh akan memberikan respon fisiologis pertumbuhan dan perkembangan tanaman.

Beberapa zat pengatur tumbuh alami yang dapat digunakan diantaranya bawang merah dan air kelapa. Ekstrak Bawang merah mengandung zat pengatur tumbuh yaitu auksin yang paling aktif untuk 3 berbagai tanaman dan berperan penting dalam pemacuan pertumbuhan yang optimal (Husein dan Saraswati, 2010). Air kelapa mengandung senyawa organik seperti vitamin $\mathrm{C}$, vitamin $\mathrm{B}$, hormon auksin, giberelin dan sitokinin. Air kelapa muda juga mengandung air, protein, karbohidrat, mineral, vitamin, sedikit lemak, $\mathrm{Ca}$, dan $\mathrm{P}$ dan merupakan sumber alami hormon tumbuh yang dipergunakan untuk memacu 
pembelahan sel dan juga merangsang pertumbuhan.

\section{METODE PENELITIAN}

\section{A. Waktu dan Tempat}

Percobaan ini dilakukan di kebun percobaan Aripan, Balai Penelitian Tanaman Buah Tropika, Solok, Sumatera Barat, dengan ketinggian tempat $435 \mathrm{~m}$ dpl. Kegiatan ini dilaksanakan selama 2 bulan yaitu mulai dari 4 Maret - 3 Mei 2021 .

\section{B. Alat dan Bahan}

Alat yang digunakan adalah gunting setek. Bahan yang dipakai adalah ranting (cabang) jambu biji varietas bipara, polybag $18 \times 25 \mathrm{~cm}$, bawang merah, air kelapa, plastik sungkup $14 \mathrm{~m}$, tanah ultisol, tali rafia, dan baskom.

\section{Metode Pelaksanan}

Percobaan ini dilakukan dengan dua perlakuan yaitu berbagai ZPT alami dan ukuran diameter batang. ZPT yang digunakan yaitu bawang merah dan air kelapa serta ukuran diameter yang digunakan yaitu diameter batang kecil $(0,3-0,5) \mathrm{cm}$, dan diameter batang besar $(0,7-1,5) \mathrm{cm}$ yang terdiri dari 6 kombinasi perlakuan sebagai berikut:

$\mathrm{A} 1=(0,3-0,5) \mathrm{cm}+$ ZPT bawang merah

$\mathrm{A} 2=(0,7-1,5) \mathrm{cm}+\mathrm{ZPT}$ bawang merah

$\mathrm{A} 3=(0,3-0,5) \mathrm{cm}+\mathrm{ZPT}$ air kelapa

$\mathrm{A} 4=(0,7-1,5) \mathrm{cm}+\mathrm{ZPT}$ air kelapa

A5 $=(0,3-0,5) \mathrm{cm}$ tanpa ZPT (kontrol)

A6 $=(0,7-1,5) \mathrm{cm}$ tanpa ZPT (kontrol).

Parameter pengamatan.

1. Persentase tumbuh (\%).

2. Hari mucul tunas (hmt).

3. Jumlah tunas

4. Panjang tunas $(\mathrm{cm})$.

5. Jumlah daun (helai).

6. Persentase setek yang berkalus $(\%)$

7. Persentase setek yang berakar (\%).

\section{HASIL DAN PEMBAHASAN}

\section{Persentase Tumbuh dan Hari Muncul Tunas}

Berdasarkan pengamatan yang telah dilakukan didapatkan hasil seperti tertera pada Tabel 1 berikut :
Tabel 1. Persentase Tumbuh dan rata -Rata Hari Muncul Tunas Setek Jambu Biji Dengan Perlakuan Pemberian Beberapa ZPT Alami dan Ukuran Diameter Batang.

\begin{tabular}{|c|c|c|}
\hline \multirow[b]{2}{*}{ Perlakuan } & \multicolumn{2}{|c|}{ Parameter Pengamatan } \\
\hline & $\begin{array}{l}\text { Persentase } \\
\text { tumbuh }(\%)\end{array}$ & $\begin{array}{l}\text { Rata - rata } \\
\text { hari muncul } \\
\text { tunas (hmt) }\end{array}$ \\
\hline $\mathbf{A 1}$ & 80 & 15,0 \\
\hline A2 & 100 & 14,2 \\
\hline A3 & 80 & 14,8 \\
\hline A4 & 100 & 14,4 \\
\hline A5 & 60 & 16,6 \\
\hline A6 & 100 & 16,6 \\
\hline
\end{tabular}
pertumbuhan setek jambu biji dari beberapa perlakuan yang di uji, persentase tumbuh tertinggi yaitu pada perlakuan A2, A4, dan A6 dengan persentase tumbuh sebesar $100 \%$, sedangkan rata rata hari muncul tunas tercepat yaitu pada perlakuan A2 yaitu 14,2 hari.

Berdasarkan Tabel 1 persentase tumbuh setek jambu biji pada perlakuan A2 A4 dan A6 (memberikan hasil tertinggi yaitu $100 \%$, sedangkan hasil persentase tumbuh terendah yaitu pada perlakuan A5 sebesar $60 \%$. Hal ini terlihat bahwa tingginya persentase setek yang tumbuh terjadi pada bahan setek yang berdiameter besar. Besarnya diameter batang akan menghasilkan cadangan bahan makanan berupa karbohidrat dan nitrogen cukup tersedia untuk pertumbuhan setek sehingga menghasilkan persentase tumbuh setek yang tinggi.

Setelah tiga minggu penyetekan, pada perlakuan A1 mulai memperlihatkan adanya tunas sampel yang layu dan tanaman akhirnya mati (20\%) dengan persentase tumbuh $80 \%$. Hal ini juga terlihat pada perlakuan A5 (diameter 0,3-0,5 $\mathrm{cm}$ kontrol) dengan persentase tumbuh hanya $60 \%$. Adanya pengaruh ukuran diameter setek terhadap persentase tumbuh disebabkan oleh banyaknya jumlah ketersediaan cadangan makanan pada bahan setek yang dapat dipakai oleh setek sebagai sumber energi untuk tumbuh. Menurut Harjadi (1991), karbohidrat dari hasil fotosintesis digunakan tanaman sebagai energi untuk proses fisiologis dalam membangun sel - sel baru. Sebagian karbohidrat akan di translokasikan ke titik tumbuh dan batang yang selanjutnya digunakan dalam proses pembelahan, pemanjangan, dan penebalan sel. 
Rata - rata hari muncul tunas tercepat dihasilkan oleh perlakuan A2. Rata - rata muncul tunas paling lambat terdapat pada perlakuan A5 dan A6 yaitu pada hari ke 16,6. Namun tunas pada masing - masing perlakuan ada yang mati pada hari ke 21,3. Hal ini diduga karena cadangan makanan pada masing - masing bahan setek berbeda - beda tergantung ukuran dari bahan setek tersebut, sehingga mempengaruhi hari muncul tunas pada setek. Menurut Sukarmin dalam Gusti (2019), laju pertumbuhan tunas dan daun pada setek tidak diimbangi dengan laju pertumbuhan akar, sehingga perkembangan tunas dan daun hanya memanfaatkan cadangan makanan pada batang yang dijadikan bahan setek, yang kemudian menyebabkan tanaman mati secara perlahan akibat kehabisan cadangan makanan.

\section{Jumlah Tunas, Panjang Tunas dan Jumlah} Daun

Tabel 2. Rata - Rata Jumlah Tunas, Rata Rata Panjang Tunas, dan Rata - Rata Jumlah Daun Setek Jambu Biji dengan Perlakuan Pemberian ZPT Alami dan Ukuran Diameter Batang.

\begin{tabular}{cccc}
\hline \multirow{2}{*}{ Perlakuan } & \multicolumn{3}{c}{ Parameter Pengamatan } \\
\cline { 2 - 4 } & $\begin{array}{c}\text { Rata }- \\
\text { rata } \\
\text { jumlah } \\
\text { tunah } \\
\text { (buah) }\end{array}$ & $\begin{array}{c}\text { Rata- } \\
\text { rata } \\
\text { panjang } \\
\text { tunas }(\mathbf{c m})\end{array}$ & $\begin{array}{c}\text { Rata }- \\
\text { rata } \\
\text { jumlah } \\
\text { daun } \\
\text { (helai) }\end{array}$ \\
\hline A1 & 2,6 & 1,04 & 2,2 \\
A2 & 3,2 & 1,74 & 5,6 \\
A3 & 2,4 & 0,82 & 1,2 \\
A4 & 3,0 & 1,66 & 4,6 \\
A5 & 1,2 & 0,90 & 0,8 \\
A6 & 2,4 & 1,26 & 2,0 \\
\hline
\end{tabular}

\section{Jumlah Tunas}

Rata - rata jumlah setek yang bertunas yang tertinggi yaitu terjadi pada perlakuan A2 yaitu 3,2 tunas dikarenakan bawang merah dapat merangsang pertumbuhan tunas dengan baik. Muncul tunas tersebut sangat terlihat bahwa pada ukuran diameter besar dan ZPT alami bawang merah mencapai parsentase tertinggi untuk munculnya tunas pada setek jambu biji yang disebabkan karena auksin dapat membelah organ untuk pertumbuhan tunas. Salah satu indikator keberhasilan dalam pertumbuhan setek yaitu terbentuknya tunas. Tunas tersebut dapat dilihat mulai muncul pada bagian ujung stek jambu biji, tunas muncul disebabkan ZPT alami yang digunakan yang memiliki kandungan untuk pertumbuhan tunas dengan baik. Menurut Prastowo et al., ( 2006), pertumbuhan tunas setek dipengaruhi oleh beberapa faktor yang saling berkaitan, seperti bahan setek yang digunakan, lingkungan tumbuh dan perlakuan yang diberikan pada setek. Hal ini juga sesuai dengan pendapat Febriana (2009), bahwa pembentukan tunas terjadi karena adanya proses morfogenesis antara interaksi pertumbuhan dengan diferensiasi oleh beberapa sel pemacu terbentuknya organ.

\section{Panjang Tunas $(\mathbf{c m})$}

Rata - rata panjang tunas terpanjang yaitu pada perlakuan A2yaitu sebesar $1,74 \mathrm{~cm}$ dan panjang tunas terendah terdapat pada perlakuan A5 sebesar $0,9 \mathrm{~cm}$. Pertambahan panjang tunas mengikuti peningkatan diameter setek, hal ini menunjukkan bahwa semakin besar diameter setek yang digunakan, peningkatan panjang tunas akan semakin cepat.

Hormon pada tumbuhan juga memegang peranan penting dalam proses perkembangan dan pertumbuhan seperti auksin, banyak terdapat pada ujung koleoptil, sehingga mendorong pemanjangan dan pucuk, meransang pertumbuhan akar adventif pada batang dan memacu dominasi tunas apical (tunas diujung batang). Ukuran diameter batang yang besar memiliki ketersediaan cadangan makanan lebih banyak dibanding dengan diameter kecil, semakin menjauh dari pucuk maka diameter batang semakin membesar dan perbedaan diameter tersebut berpengaruh langsung terhadap kemampuan setek membentuk akar dan tunas karena adanya perbedaan pada tipe serta variabilitas karbohidrat dan bahan tersimpan lainnya.

\section{Jumlah Daun (helai)}

Rata - rata jumlah setek berdaun terbanyak didapatkan pada perlakuan A2 yaitu sebanyak 5,6 helai dan jumlah daun paling sedikit yaitu pada perlakuan A5 sebanyak 0,8 helai. Tunas tersebut juga merupakan tahapan penting dalam pembentukan primordia daun pada pertumbuhan stek. Menurut Berlian dalam Yoseva (2017), menyatakan bahwa auksin dan vitamin B1 (Thiamin) yang terdapat dalam ekstrak bawang merah mampu untuk meransang pertumbuhan akar dan tunas. Cepat lambatnya muncul tunas akan mempengaruhi panjang tunas, sehingga tunas yang lebih panjang akan memiliki tempat tumbuh daun yang lebih banyak. Daun merupakan organ tanaman yang memiliki jumlah klorofil terbesar untuk proses fotosintesis tanaman. 
3. Persentase Setek yang Berkalus dan Persentase setek yang berakar

Tabel 3. Persentase Jumlah Setek yang Berkalus (\%) dan Persentase Jumlah Setek yang Berakar (\%).

\begin{tabular}{ccc}
\hline \multirow{2}{*}{ Perlakuan } & \multicolumn{2}{c}{ Parameter Pengamatan } \\
\cline { 2 - 3 } & $\begin{array}{c}\text { Jumlah setek } \\
\text { yang berkalus } \\
(\%)\end{array}$ & $\begin{array}{c}\text { Jumlah setek } \\
\text { yang } \\
\text { berakar (\%) }\end{array}$ \\
\hline A1 & 0 & 0 \\
A2 & 0 & 0 \\
A3 & 0 & 0 \\
A4 & 0 & 0 \\
A5 & 0 & 0 \\
A6 & 0 & 0 \\
\hline
\end{tabular}

Tabel 3 memperlihatkan bahwa hasil pengamatan setek jambu biji dengan parameter pengamatan persentase setek yang berkalus pada semua perlakuan $0 \%$, dan persentase jumlah setek yang berakar $0 \%$.

Persentase setek yang berkalus pada masing - masing perlakuan yaitu $0 \%$ dan persentase setek yang berakar juga $0 \%$. Hal ini disebabkan pertumbuhan kalus dan akar setek belum terbentuk. Sistem perakaran berhubungan erat dengan jumlah daun, yaitu laju pertumbuhan akar dan penyerapan hara ditentukan oleh pemasokan hasil fotosintesis. Pembentukan akar diawali dengan metabolisme cadangan nutrisi yang mengubah karbohidrat menjadi gula sehingga menghasilkan energi yang mendorong pembentukan primordia akar menjadi akar.

Menurut Baessler (2020), pertumbuhan dan perkembangan akar mulai muncul pada umur 6 -8 minggu. Hal ini juga diduga karna ZPT yang terkandung dalam setek jambu biji secara alami belum mencukupi dengan adanya penambahan pemberian ZPT alami masih belum mampu untuk menumbuhkan akar sampai akhir pengamatan tidak terbentuk perakaran. Kemungkinan pemberian ZPT bawang merah dan air kelapa belum mencukupi sehingga absorbsi larutan ZPT kurang optimal. Dengan tidak terjadinya pertumbuhan akar setek maka kebutuhan unsur hara dan air tidak dapat dipenuhi untuk kebutuhan proses metabolisme setek, yang akibatnya energi untuk pertumbuhan makin menurun yang pada akhirnya tanaman layu dan mati.

Zat pengatur tumbuh yang mempengaruhi kemampuan setek untuk berakar dan bertunas adalah sitokinin dan auksin. Pertumbuhan setek mempunyai kelemahan yaitu tidak adanya pertumbuhan akar untuk masing - masing bagian cabang karena adanya perbedaan kandungan karbohidrat dan auksin. Menurut Panjaitan et al (2014), pembentukan akar pada setek dapat didorong oleh adanya zat pengatur tumbuh auksin dengan cara mengalokasikan penyebaran fotosintat pada akar untuk meningkatkan pertumbuhan akar tersebut. Muswita (2011), mengungkapkan bahwasanya perakaran akan mendorong terjadinya metabolisme tumbuhan karena penyerapan air dan hara pada akar yang akan digunakan oleh tumbuhan.

Berbagai perlakuan ZPT alami yang terbaik dan ukuran diameter yang berbeda mampu menghasilkan pertumbuhan tunas setek tertinggi yaitu pada perlakuan A2 menggunakan diameter ukuran 0,7 - 1,5 cm dan ZPT alami bawang merah. Tetapi fungsi dari ZPT bawang merah untuk pertumbuhan akar kurang maksimal dikarenakan perendaman kurang lama pada setek sehingga tidak membentuk akar. Perlakuan yang terendah terdapat pada perlakuan A5 diameter ukuran $0,3-0,5 \mathrm{~cm}$ tanpa ZPT yang terlihat jelas bahwa pertumbuhan dan perkembangan dari beberapa parameter pengamatan yang paling terendah pada setiap pengamatan yang dilakukan. Hal tersebut dikarenakan tidak adanya zat atau kandungan yang mampu berperan baik dan tidak merangsang dengan baik pada pertumbuhan setek jambu biji.

Penggunaan diameter yang besar memberikan pertumbuhan setek jambu biji yang lebih tinggi. Penggunaan diameter setek yang berbeda mencerminkan perbedaan tingkat ketuaan jaringan setek, semakin besar diameter, semakin lanjut perkembangan jaringan setek, sebaliknya semakin kecil diameter setek, semakin muda jaringan setek. Hasil yang sama dilaporkan oleh Santoso et al. (2008), bahwa perbedaan diameter setek menghasilkan pertumbuhan tanaman yang berbeda pada jarak pagar.

Perlakuan A5 memberikan hasil yang rendah pada setek yang bertunas, berdaun, panjang tunas dan jumlah tunas dikarenakan kandungan dan ZPT tidak diberikan pada perlakuan ini, bahan yang digunakan yaitu ukuran diameter setek yang kecil sehingga pertumbuhan setek kurang baik. Pertumbuhan setek jambu biji membutuhkan beberapa kandungan dari ZPT alami yang diserap tanaman, akan tetapi pada perlakuan ini kandungan ZPT yang diserap setek sedikit bahkan tidak ada sehingga mengakibatkan hasil pertumbuhan setek kurang baik. 


\section{KESIMPULAN}

1. Pemberian ZPT alami dan perbedaan ukuran diameter batang berpengaruh terhadap persentase tumbuh, hari muncul tunas, jumlah tunas, panjang tunas, dan jumlah daun pada setek jambu biji.

2. Ukuran diameter setek batang $0,7-1,5 \mathrm{~cm}$ dengan pemberian ZPT alami bawang merah memberikan pertumbuhan setek jambu biji yang terbaik

\section{DAFTAR PUSTAKA}

Abidin. 1985. Tentang Zat Pengatur tumbuh yang sangat berpengaruh terhadap tumbuhnya perakaran.

Baessler. L. 2020. Guava Cutting Propagation.https://www.gardeningknowh ow.com/edible/fruits/guava//growingguava-tree-cuttings.

Cahyono, Bambang. 2010. Sukses Budidaya Jambu Biji di Pekarangan dan Perkebunan. Lyli Publisher : Andi. Yogyakarta.

Fanesa, A. 2011. Pengaruh Pemberian Beberapa Zat Pengatur Tumbuh Terhadap Pertumbuhan Setek Pucuk Jeruk Kacang (Citrus nobilis L.), Jurusan Budidaya pertanian FAKULTAS pertanian, Universitas Andalas.

Febriana, S., (2009), Pengaruh Pemberian Konsentrasi Zat pengatur Tumbuh dan Panjang Stek Terhadap Pembentukan Akar dan Tunas pada Stek Apokad (Persea Americana Mill.), Skripsi, Institut Pertanian Bogor, Bogor.

Gunawan, E. (2014). Perbanyakan Tanaman. PT Agromedia Pustaka. Jakarta.

Gusti, M. (2019). Penggunaan Berbagai Jenis ZPT terhadap Pertumbuhan Vegetatif Setek Batang Jambu Air Citra (Syzygium aqueum Murr.), LTA, Politeknik Pertanian Negeri Payakumbuh. Tanjung Pati.

Harjadi, S. S. 1991. Pengantar Agronomi. Gramedia. Jakarta.

Hartmann, H.T., D. E. Kester, F. T. Davies, Jr, R. L. Geneve. 2002. Plant Propagation: Principles and Practices. 7th edition. Prentice Hall Inc. 770p.

Huik E. M. 2004. Pengaruh Rootone - F dan Ukuran Diameter Setek Terhadap Pertumbuhan Dari Setek Batang Jati ( Tectona Gandis L. F). Jurusan Kehutanan Fakultas Pertanian Universitas Pattimura.
Husein, E., saraswati, R. 2010, Rhizobakteri Pemacu Tumbuh Tanaman. Pupuk Organik dan Pupuk Hayati, 191 - 209.

Imelda. 2008. Golongan yang terdapat dalam ZPT yang digunakan untuk stekan yang dilakukan.

Mayasari E, Lukas S. Budipramana, YS. Rahayu. 2012 Pengaruh Pemberian Filtrat Bawang Merah dengan Berbagai Konsentrasi dan Rootone - F terhadap Pertumbuhan Setek Batang tanaman Jambu Biji ( Psidium guajava L.). jurnal Lentera Bio 1 (2) : 99 103.

Muswita. 2011. Tentang hal - hal yang terurai dalam bawang terhadap perangsangan untuk muncul kalus dan perakaran pada stekan.

Panjaitan LRH,. Ginting J., Haryati. 2014. Respon pertumbuhan berbagai ukuran diameter setek bougenvil (Baugainvilea spsctabilis Wild) terhadap pemberian zat pengatur tumbuh. Jurnal online agroekoteknologi 2(4) : $1384-1390$.

Prastowo dan Roshetko. 2006. Teknik pembibitan dan perbanyakan vegetatif tanaman buah. Buku perbanyakan Tanaman. Diakses tanggal 04 Desember 2015.

Priyono \& Danimihardja, S. (1991). Reproduksi Embrio Somatik Kopi Arabika pada kultur in vitro II Pengaruh Macam dan Konsentrasi Sitokinin. Pelita Perkebunan. $7(1), 1-6$.

Ratna Dewi A, Intan. 2008. Peranan dan Fungsi Fitohormon bagi Pertumbuhan Tanaman. Bandung : Universitas Padjadjaran.

Santoso, B. B., Hasnam, Hariyadi, S. Susanto, B. S. Purwoko. 2008. Perbanyakan vegetatif pada pemuliaan pohon. Makalah Gelar Teknologi di Pekanbaru Riau dalam rangka pemasyarakatan Hasl Litbang Kehutanan, 21 Agustus 2008.

Wudianto, R. 2001. Membuat Stek, Cangkok dan Okulasi. Penebar Swadaya. Jakarta. 72 Hal.

Yoseva, S,. Nurbaiti, Tarigan L.P. 2017. Pemberian Ekstrak Bawang Merah Sebagai Zat Pengatur Tumbuh Alami Pada Pertumbuhan Setek Lada Hitam (Piper migrum L.). Jurusan Agroteknologi Fakultas Pertanian. Universitas Riau. Pekanbaru. 